\title{
Management of Internally Generated Revenue (IGR) and Sustainability of University Education in Cross River State, Nigeria
}

\author{
Dr. (Mrs) N. N. Ukpong \\ Uzoigwe, Michael Chukwudi \\ Department of Educational Administration and Planning, \\ Faculty of Education, University of Calabar, Calabar, Cross River State
}

\begin{abstract}
The study assessed the management of internally generated revenues (IGR) and sustainability of University education. The area of the study was Cross River State. Survey research design was adopted for the study. The study population was the principal officers in the management and administrative cadre of the Universities. Census sampling approach was used to select all the principal officers of the Universities because the population was manageable. A total number of fifty (186) management staff was used. Management of Internally Generated Revenue and Sustainability of University Education Questionnaire (MIGRSUEQ) was used to elicit information from the respondents. The instrument consisted of two parts: Part one was used to gather the demographic data of the respondents. Part two sought information on the major sub-variables of the study. A draft of the research instrument was presented to experts in Educational Administration, Measurement and Evaluation for validation. They made useful corrections and suggestions which were carefully effected to give the content and face validity of the instrument. A prior study was carried out to ascertain the level of reliability of the research instrument. The internal consistency index using a Cronbach Alpha test was thus computed and established at 0.89 . This was considered reliable enough for the study. One-Way Analysis of Variance (ANOVA) and Multiple Linear Regression statistics were used to analyse the data collected for the study. Findings revealed that the management of internally generated revenue significantly influenced the sustainability of University education. It was also found that investment income, school charges and consultancies were significant predictors of sustainability of University education in Cross River State. The study recommended that each University management should create an automated IGR management system to prevent fraud and maintain privacy \& secrecy during revenue remittent using customized fee automatic backup \& upgrades for sustainability of University education in Cross River State. Also, the University managements should electronically make attractive the profit sharing formula between the central administration and the departments where IGR is generated.
\end{abstract}

Keywords: Management, Internally Generated Revenue, Sustainability, University Education DOI: $10.7176 / \mathrm{JEP} / 10-5-11$

\section{Background to the study}

The concept of developmental sustainability has currently assumed much relevance not only to environmental and biodiversity issues but also to education practice. Education for sustainability is the practice of learning how to achieve global and local sustainable communities. It is a vision of education that seeks to balance human's needs and economic wellbeing with cultural traditions and respect for the earth's natural resources. The desired outcome is to inform and engage citizenry with the social, economic and ecological literacy, creative problemsolving skills and commitment necessary to enhance sustainable life in the present and in the future.

Sustainability of University education means the ability of higher institutions of learning to survive in this period of global competitiveness through effective management of internally generated revenue services since the government alone could no longer pilot the affairs of funding higher education. This means that sustainable development is a process in which the exploitation of resources, direction of investment, orientation of technological development and institutional changes are made consistent with the future as well as the present (Akpan, 2015). Education for sustainable development is relevant to learning at all levels of education including University education and has to be integrated into the teaching-learning process. According to Otomewo (2018), higher education has been speculated to be dysfunctional as a result of several problems both within and outside the school system.

In Cross River State higher institutions, the proper and result-oriented management of University education for sustainability is what most stakeholders in education desire and agitate for. Unfortunately, the learning environments in the public Universities are very poor and not in any way conducive for sustainable teaching and learning. Bamino (2017) observed that eroded intellectuals of the academia were due to poor quality of lecturers who may have been employed as a result of unemployment challenges in other sectors. There are insufficient infrastructural and instructional facilities such as functional libraries, laboratories, recreational facilities, well 
equipped lecture halls and workshops. Higgs and Macmillan (2016) submitted that in some Faculties, teachinglearning takes place in decrepit buildings. Furthermore, lecturers' use of appropriate teaching strategies such as experimentation and inquiry in teaching is not just a mirage but it is yet to reach an appreciable level. PercySmith (2018) pointed out that to ensure sustainability in higher education; institutional administrators should adopt practical and experimental learning method which will enable the learners to act on their learning in respect of sustainable life styles.

However, if sustainable University education is seen as a value and a vision, and also a cultural practice of the University rather than simply a mere transfer of a set of skills and knowledge, these will enable the students to become actors of change as well as learners. It will reduce skill shortages through the production of skilled manpower that are intrinsically relevant to the needs of the labour market. This fact was supported by Higgs and Macmillan (2016) who asserted that to ensure sustainable University education, sustainability should be addressed through individual staff and teachers as role models and curriculum implementers. These would promote both learning about sustainability and adoption of sustainable behaviour. This means that, to actualize sustainable University education, these indices of sustainability (quality teaching, learning facilities and school environment) must be given proper and urgent attention by stakeholders through effective and efficient management of internally generated revenues.

Another strategic dimension of sustainable University education has to do with the relevance of curriculum contents to the learners. If the curriculum is relevant to students' life and future, the students would be interested in learning about sustainability. There will be the quest for practical knowledge leading to more sustainable lives. They would develop more positive attitudes to learning, better behaviour, regular attendance, improved standards and achievements, hence achieve their immediate needs without compromising that of the future generation. This depicts that sustainability is a significant factor in improving teaching and learning in the University. Gayford (2018) stated that in most highly ranked Universities in the world, sustainability is an integral element of a well-planned curriculum alongside quality teaching with excellent learning facilities in a conducive school environment and these enhanced students' attitudes toward sustainable learning.

However, the extent to which sustainable University education can be achieved depends greatly on the different management strategies of internally generated revenues which is the focus of this paper. Internally generated revenues are monies collected by institutional administrators through imposition of school charges, tuition fees, investment income, grants, gifts, endowment, and consultancies as a means of fundraising within the school system as opposed to monies from government trust funds. Since fundraising is now a norm in both public and private higher institutions in order to sustain the needs of the school, management of internally generated revenue helps to complement towards the yearly budgeted necessary expenses.

School charges are the costs of late payment of school fees at stipulated period by the school management. While tuition fees are the cost of learning materials used by students to make items which they take away from school, non-curriculum excursion costs, and any additional support and service fees that may be incurred by students with additional needs and other services. Investment income is the revenue which comes from interest payments, dividends, capital gains collected upon the sale of a security or other assets, and any other profit made through an investment of any kind. Generally, Universities earn most of their total net income each year through regular employment income. Grants are non-repayable funds or products disbursed or given by a government regulatory agency, corporation, foundation or trust, to the University, often a nonprofit entity, educational institution, business or an individual. A financial endowment is a donation of money or property to a nonprofit organization for the ongoing support of that organization.

According to Brech as cited in Adeniyi (2014:2), management is a social process entailing the responsibility for the effect of economic planning and regulations of operations of an enterprise and fulfillment of a given task. Similarly, Uzoigwe (2014) sees management as the art and science of developing and strengthening the knowledge, skills, instincts and resources that individuals and school organization must need to survive in a dynamic environment for the attainment of predetermined goals. Uchendu and Akuegwu (2016) submitted that management is not only meant to exist in name, it is action and practice oriented for excellence because good management of education breeds good results. As clearly spelt out, funds constitute part of resources that must be well managed for sustainability. The role funds management play in the achievement of educational goals and objectives cannot be over-emphasized. Administrators utilize school charges and tuition fees for continuing to provide students with a high quality education, maintaining and expanding facilities, ensuring that the welfare of the staff, and their families is given due consideration.

However, there exists a culture of poor management of school charges and tuition fees by the majority of institutional administrators in the University system. This culture in University administration needs to be changed if the sustainability of University education is to be achieved. It is observed that University administrators are not adequately managing generated school charges, tuition fees, grants, gifts, endowment, fees and charges, among others for the sustainability of University education in Cross River State. Most times, the graduates are issued fake clearance from the bursary after some negotiations over late registration fees at the 
detriment of the University account. The needed basic revenues that are internally generated are either not available or if available are rather racketeered or misappropriated. Some of the commercial ventures and the IGR proceeds were not used to provide services such as staff welfare, maintenance of facilities and beautification of the university premises (Ofoegbu and Alonge, 2016). The University cannot pay their Consultancies staff and contractors for quality teaching services since the accruing errors and frauds relating to school charges and endowments are not timely detected and prevented in the University (Omodere, Ekwe \& Ihendinihu, 2018). The University management cannot purchase quality learning facilities for conducive learning environment since high misappropriation of grants and investment income are not accounted for. They are not ensuring that financial records are complete and accurate and that transactions are properly authorised. The University management cannot safeguard the assets and profits of the organisation from misuse, error, theft or waste. They are not ensuring the accuracy and reliability of accounting records for timely payment of University personnel. Above all, the accounting units are not ensuring adherence to management laid down policies and procedures with regards to school business.

Poor management of internally generated revenue in higher education may have a negative effect on the products of the educational process vis-a-vis sustainable University education. It is against this background, that the researchers were motivated to investigate the influence of management of internally generated revenue on the sustainability of University education in Cross River State, Nigeria. The sub-variables of internally generated revenue considered in this study were school charges, tuition fees, investment income, grants, gifts, endowment, and consultancies. While the sub-variables for sustainable University education includes quality teaching, learning facilities and school environment.

Edet and Osika (2018) investigated the alternative strategies of financing secondary school education for sustainable development in Cross River State. Three research questions guided the study. Survey research design was adopted for the study. The population consisted 232 principals out of which 200 constituted the sample. Alternative Strategies of Financing Secondary Education and Sustainable Development Questionnaire (ASFSESDQ) was the instrument used for data collection. Percentages, mean and standard deviation were used to answer the research questions. Result indicated that: PTA funds and school investment funds influences sustainable development of public secondary schools in Cross River State. It was recommended among others that there should be commitment by the principals, teachers, parents and the community toward generating funds for sustainable development of secondary schools in Cross River State.

Ofoegbu \& Alonge (2016) designed a descriptive survey to identify the major sources and utilization of internally generated financial revenue by Nigerian University administrators. The analysis revealed that commercial ventures were among the main sources of IGR while the proceeds were used for services including staff welfare, maintenance of facilities and beautification of the university premises. A further analysis of data showed that there was a significant relationship between internally generated resources and the management/ development of universities in Southern Nigeria. It was recommended that university administrators should be more transformative in their leadership style in order to strengthen their revenue base for effectiveness in University management.

Afutu (2015) explored the sources, challenges and sustainability of internally generated fund at university of education, Winneba. It came to light from the study that most of the sources of Internally Generated Fund for the university can be sustainable by constant increase of enrolment and commercialization of departmental activities like printing/ publication section and clothing service department. It was concluded that in order for the university to increase revenue from its commercialized activities, the university can come out with new marketing strategies to attract the public to buy into its commercial and other revenue generation activities. The study recommended that management of universities should put in place effective measures that would ensure that those IGR sources that contribute huge amount of revenue on the activities of the universities (sale of farm products, sale of admission forms, residential and academic facilities user fees and sandwich fees) are improved upon and efficiently managed to ensure long-term sustainability

In the same vein, Adesoji and Chike (2013) examined the effect of internal revenue generation on infrastructural development. The result showed that there is a positive relationship between internally generated revenue and infrastructural development. The study also revealed the various methods of generating internal revenue, which are the enforcement of tax personnel, contribution, and creating awareness to the public. The findings of the study however showed that revenue administration agencies need to be reviewed to generate more revenue in the country. Also, Aja-Okorie (2013) ex-rayed the strategies for improving the Internal Generated Revenue (IGR) base of Ebonyi State University, Abakaliki. The study specifically focused on how the establishment of vocational centre, sport clubs, and skills acquisition centres in the universities could improve the IGR generation in the EBSU, Abakaliki. The design of the study was descriptive survey design. The results of the study showed that the establishment of entrepreneurship training centres in the University can enhance the IGR of the State University, that the University partnership programmes or collaboration with other institutions can improve the University internally generated revenue base and that adoption and efficient utilization of e- 
payment of school fees and online registrations can help to increase the Internal Generated Revenue of the University. Based on these findings, the study recommended among other things that University managers should establish entrepreneurship training centres in Ebonyi State University to improve the sources of Internally Generated Revenue.

Wordu (2018) examined the impact of internally generated revenue in development of tertiary educational institutions in Rivers State, Nigeria. The findings revealed that the federal and state institutions had disparity in the sources of internally generated revenue, and there is no doubt that the internally generated revenue initiative of tertiary educational institutions in the state is at its early stage of development. It was therefore recommended that investment should be made into projects that generate additional funds for the institutions and the institutional creativity in revenue generation should be paramount to both faculty and department.

Akinsolu (2012) investigated the relationship between resource utilization and internal efficiency indicators in Nigeria public secondary schools. The purpose of the study was to find out whether public secondary schools in the country make the best use of resources allotted in turning out graduates with minimal wastage. Four null hypotheses were generated to guide the study. Out of the four hypotheses generated, one was rejected while three were accepted. The correlation matrix table showed that all variables of resource utilization had positive relationship with internal efficiency. This attested to the fact that resources are vital for educational system production function. Mohammed, Ahmed \& Salihu (2015) examined the relationship between expenditure (both Capital and recurrent) and internally generated revenue (IGR) in Adamawa State local governments. The study finds a significant relationship between government expenditure and internally generated revenue. Capital expenditure and recurrent expenditure on agriculture and natural resources, roads, rural electrification, market expansion significantly influence the internally generated revenue of the Adamawa State's local governments.

Omodere, Ekwe \& Ihendinihu (2018) investigated the impact of internally generated revenue (IGR) on economic development of Nigeria. The statistical tool used for the data analysis was the multi-regression and ttest for test of hypotheses. The findings of the study revealed that TIGR, SIGR and LIGR have robust and significant positive impact $(\mathrm{p}$-value $=0.000<0.05)$ on RGDP, while FGIR also indicated positive and significant influence on RGDP. There was an existence of high correlation between the dependent and independent variables. The study concluded that the positive impact of IGR is not out of place but the physical evidence is apparently lacking and therefore government policies that could eradicate sharp practices in the government system are required.

\section{STATEMENT OF THE PROBLEM}

The proper and result-oriented management of University education for sustainable development in Cross River State is what most stakeholders in education are desiring and have been agitating for. Unfortunately, lack of sustainability in University education in terms of incompetent teaching personnel, learning facilities and school environment has degenerated into production of half-baked graduates from the Universities. It is observed that the learning environments in some Universities are not supportive of education for sustainable development. Educators as well as members of the public, tend to blame this on ineffective management of educational resources including internally and externally generated revenues. There is paucity of infrastructural and instructional facilities such as recreational facilities, guidance and counseling facilities, laboratory materials and equipment. Moreover, lecturers' use of appropriate instructional strategies such as enquiry, practical and experimental methods to capture the interest of the students is yet to reach an appreciable level. The curriculum content does not seem to be relevant to students' life and future despite the introduction of entrepreneurial studies at all levels of education in Nigeria. Therefore, there is no quest for knowledge that would lead to more sustainable lives. However, the needed basic resources are either not available or if available are rather mismanaged or misappropriated. Lack of sustainability in University education has degenerated into all sorts of social ills including graduate unemployability, volatile and militant students' unionism, secret cults, examination malpractices and sexual harassments. Thus poor sustainability of the education sector is having a multiplier effect on the quality of education provided by the university system. Despite the effort of Federal government to make provision for external auditing, with evidence, yet the problem of managing internally generated revenue effectively to enhance sustainable University education still persists. Thus, it is pertinent to raise the question: How does management of internally generated revenue influence the sustainability of University education in Cross River State, Nigeria?

\subsection{Purpose of the study}

The purpose of the study was to determine the influence of management of internally generated revenue and sustainability of University education in Cross River State, Nigeria. Specifically, the study investigated the influence of management of:

1. School charges on the sustainability of University education in terms of quality teaching, learning facilities and school environment. 
2. The composite and relative contributions of management of internally generated revenue sub-variables to the prediction of sustainability of University education in Cross River State.

\section{RESEARCH QUESTIONS}

(1) To what extent does the management of school charges influence the sustainability of University education in Cross River State?

(2) What is the composite and relative contribution of the management of internally generated revenue to the prediction of sustainability of University education in Cross River State?

\section{RESEARCH HYPOTHESES}

(1) There is no significant influence of management of school charges on the sustainability of University education in Cross River State

(2) There is no composite and relative contribution of internally generated revenue to the prediction of sustainability of University education in Cross River State

\section{METHODOLOGY}

This research was carried out in Cross River State, Nigeria. The study area is Cross River State because it is believed to be miles away from sustainable development in terms of University education management. For instance, the National Universities Commission (NUC) did release its annual University rankings and featured University of Calabar on $28^{\text {th }}$ position and Cross River University of Technology on $91^{\text {st }}$ position, falling from a sympathetic margin of the former positions with a 53.34 percent pass to 15.65 percent pass in 2018 (The Nation, 2018). Cross River is one of the 36 states in the Republic bounded by Cameroon. It is located in the South-South geopolitical zone of the country with Calabar as the capital city. The state is located on latitude $5^{\circ} 45^{\prime}$ North of the equator and longitude $8^{\circ} 30^{\prime \prime}$ East of the Greenwich meridian. It is a coastal state in the Niger Delta and it occupies 20,156 square kilometres (Cross River State Government, 2014). Cross River State is bound in the North by Benue state, in the West by Ebonyi and Abia states, in the East by Cameroon Republic and in the South by Akwa-Ibom State and the Atlantic Ocean.

Established in 1975, University of Calabar, also called Unical is a public higher education institution currently headed by Prof. Zana Akpagu, and located in the small city of Calabar (population range of 250,000499,999 inhabitants), Cross River State. Officially accredited and recognized by the National Universities Commission, Nigeria, a very large (uniRank enrollment range: 40,000-44,999 students) coeducational higher education institution. It offers courses and programs leading to officially recognized higher education degrees such as bachelor and postgraduate degrees in several areas of study. This 43 years old higher-education institution has a selective admission policy based on entrance examinations and international applicants are eligible to apply for enrollment. Cross River University of Technology, also called CRUTECH is a State-owned higher institution located in Calabar. The University was established in 2002 after the merging of three higher institutions: the Polytechnic of Calabar, College of Education and Ibrahim Babangida College of Agriculture. The 16 year old Campus offers degree courses at undergraduate and post graduate levels. The university currently has campuses in Calabar, Obubra, Ogoja and Obudu.

This study adopted survey research design. This was because the design allowed the researchers to sample the opinions of respondents through the use of questionnaire, describe and interpret the findings based on the information obtained from the sample. It equally allowed the researcher to generalize the findings of the study to other areas that was not covered by the study. This design was chosen to examine how institutional administrators manage internally generated revenues to influence the sustainability of University education in Cross River State. The population of the study consisted of all the institutional administrators. Census and stratified random sampling techniques were used to select 186 administrators (148 males and 38 females), However, A total of 335 (15 percent) of the 2,232 final years undergraduate students from four Faculties (Social Science, Education, Sciences, and Management Sciences) in Unical and Crutech were randomly sampled to assess their administrators. The final year undergraduate students were sampled for the study because the researchers believed that they could provide unbiased information, and they had had the impact of the University environment from the outset of their programme for not less than three years prior to graduation. A 20-item questionnaire designed on a four-point modified Likert scale and titled: Management of Internally Generated Revenue and Sustainability of University Education Questionnaire (MIGRSUEQ) was used to elicit information from the respondents. The instrument was validated by experts in Measurement and Evaluation as well as Educational Administration and Planning. The reliability 0.89 was established using Cronbach alpha method. This value was considered appropriate for the instrument to be used for the study. Data obtained were analysed using One-way analysis of variance (ANOVA) and multiple linear regression statistics. ANOVA is applicable in this study because the independent variable is categorized into three groups and compared with the sustainability of University education which is measured continuously. The regression statistic is applicable because 
management of internally generated revenues variables is predicted on the effector variable.

\subsection{Hypothesis one}

There is no significant influence of management of school charges on the sustainability of University education. The independent variable in this hypothesis is management of school charges categorized into three levels (low, average and high), while the dependent variable is sustainability of University education measured by three indices of quality teaching, learning facilities and school environment. Based on the five items that measured management of school charges, the subjects who scored from 6-11 were classified as being low while those who scored from 12-18 were classified as being moderate and those who scored from 19-24 were classified as being high. To test this hypothesis, the mean of sustainability of University education and its sub-variables from low, average and high management of school charges were computed and compared using descriptive statistics and one-way analysis of variance (ANOVA). The results of the analysis are presented in Table 1.

TABLE 1

One-way analysis of variance of the influence of management of school charges on the sustainability of University education in terms of quality teaching,

Learning facilities and school environment

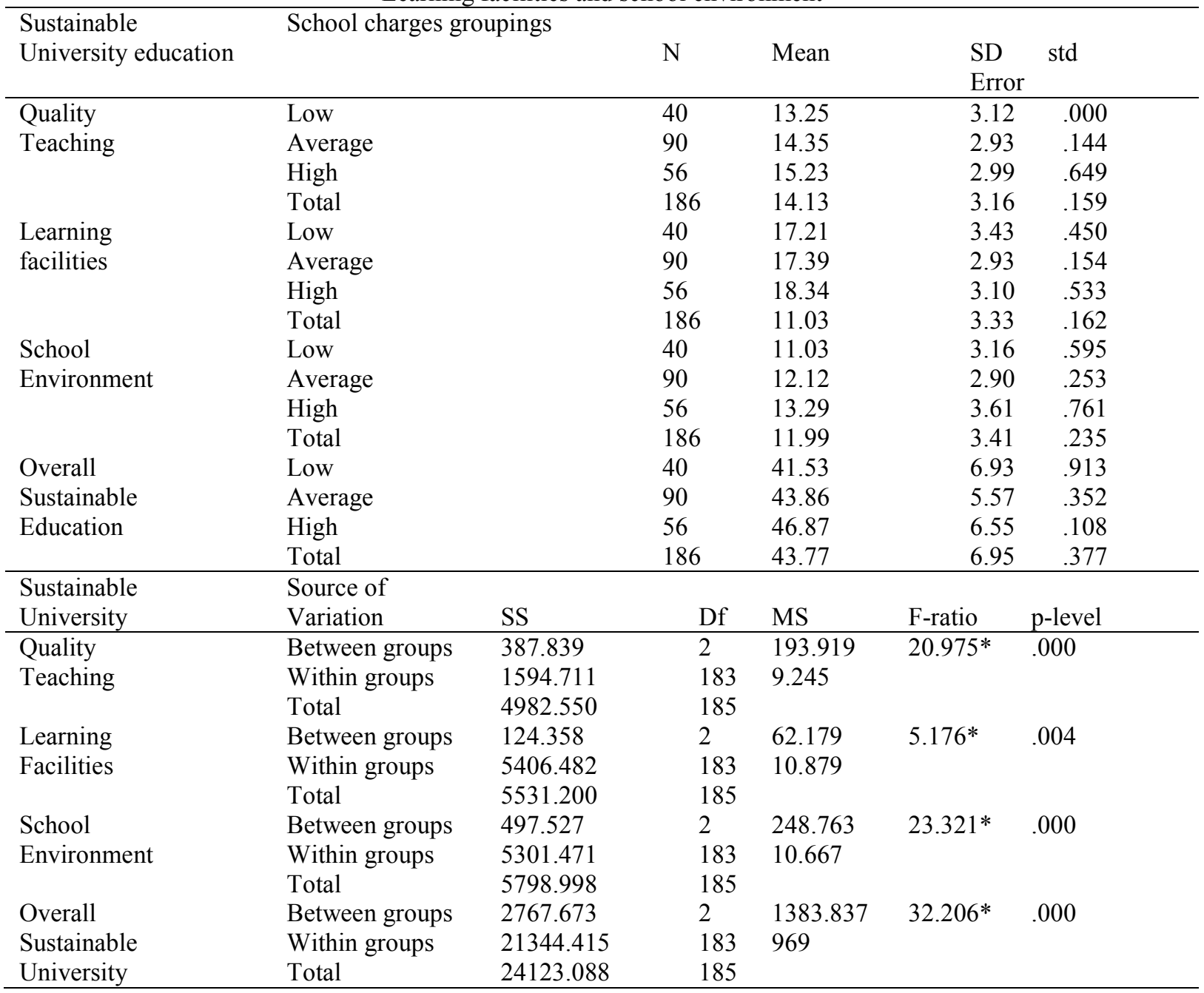

*significant .05

The upper part of Table 1 presents the means and standard deviations of sustainability of University education variables for the three categories of management of school charges (high, average and low). The result shows that group 3 (the high category), had higher mean score on all the sustainability of University education sub-variables as well as on the overall sustainability of University education, followed by group 2 (the average category), and then group 1 (the low category), in that order. This result implies that the higher the mean score on management of school charges, the better also is the sustainability of University education and vice versa.

The lower part of the table is a summary of one way analysis of variance for sustainability of University education sub-variables. The result shows that the F-ratios associated with sustainability of University education sub-variables are: $20.975,5.176,23.321,2$ and 32.206 , for quality teaching, learning facilities and school 
environment and overall sustainability of University education, respectively. These results indicate that the Fratios are statistically significant at .05 probability level $(\mathrm{p}<.05)$. On the basis of these results, hypothesis one is rejected. This implies that management of school charges significantly influences the sustainability of University education on the overall and also in terms of the three dimensions of sustainability of University education considered in this study, namely: quality teaching, learning facilities and school environment.

In order to determine the source and direction of significant difference among the categories of management of school charges, a post hoc multiple comparison test was applied, utilizing Fisher's Least Significance Difference (LSD) approach. The result of this analysis is presented in Table 2 . The table shows that significant differences exist between: low and average categories $(\mathrm{t}=3.02)$, high and low categories $(\mathrm{t}=6.42)$, and between average and high categories $(\mathrm{t}=2.29)$, for quality teaching. For learning facilities, significant differences was observed between high and low categories $(\mathrm{t}=3.27)$, and between average and high categories $(\mathrm{t}=2.28)$. However, there was no significant differences between average and low categories $(t=0.36)$. In the case of school environment, significant differences was observed between low and average categories $(\mathrm{t}=2.97)$, high and low categories $(\mathrm{t}=8.02)$, and between average and high categories $(\mathrm{t}=3.62)$. In addition, significant differences were observed between low and average categories $(\mathrm{t}=2.97)$, high and low categories $(\mathrm{t}=8.02)$, and between average and high categories $(\mathrm{t}=3.62)$, for the overall sustainability of University education.

\section{TABLE 2}

Fisher's (LSD) multiple comparison test analysis of management of school charges on the sustainability of University education in terms of quality teaching, learning facilities and school environment

\begin{tabular}{|c|c|c|c|c|}
\hline $\begin{array}{l}\text { Sustainability of } \\
\text { University } \\
\text { education }\end{array}$ & $\begin{array}{l}\text { School charges } \\
\text { groupings }\end{array}$ & Low $(n=54)$ & Average $(n=67)$ & $\begin{array}{l}\text { High } \\
(n=65)\end{array}$ \\
\hline \multirow{4}{*}{$\begin{array}{l}\text { Quality } \\
\text { Teaching }\end{array}$} & 1. Low & 13.25 & -1.097 & -1.983 \\
\hline & 2. Average & $-3.02 *$ & 14.35 & -885 \\
\hline & 3. High & $-6.42 *$ & $-2.29 *$ & 15.23 \\
\hline & & $\mathrm{MSW}=925$ & & \\
\hline \multirow[t]{4}{*}{ Learning facilities } & 1. Low & 17.21 & -.142 & -1.095 \\
\hline & 2. Average & -0.36 & 17.39 & .953 \\
\hline & 3. High & $-3.27 *$ & $-2.28 *$ & 18.34 \\
\hline & & $\mathrm{MSW}=925$ & & \\
\hline \multirow{4}{*}{ Learning environ. } & 1. Low & 11.03 & -1.090 & -2.259 \\
\hline & 2. Average & $-2.79 *$ & 12.12 & -1.169 \\
\hline & 3. High & $-6.81 *$ & $-2.82 *$ & 13.29 \\
\hline & & $\mathrm{MSW}=925$ & & \\
\hline \multirow{4}{*}{$\begin{array}{l}\text { Overall } \\
\text { Sustainability }\end{array}$} & 1. Low & $41.53^{3}$ & $-2.330^{\mathrm{b}}$ & -5.337 \\
\hline & 2. Average & $-297 * c$ & 43.86 & -3.007 \\
\hline & 3. High & $-8.02 *$ & $-3.62 *$ & 46.87 \\
\hline & & $\mathrm{MSW}=925$ & & \\
\hline
\end{tabular}

\footnotetext{
Significant at .05

a. Group means are placed on the principal diagonal

b. Difference between group means are placed above the diagonal

c. Fishers LSD t- values are placed below the diagonal

2. Hypothesis two
} 
Management of internally generated revenue variables in terms of school charges, tuition fees, investment income, grants, gifts, endowment and consultancies are not significant predictors of sustainability of University education. The independent variable is management of internally generated revenue while the dependent variable is sustainability of University education. The variables were measured continuously. To test this hypothesis, multiple regression statistical technique was used and the result is presented in Table 3.

TABLE 3

Multiple regression analysis of seven sub-variables of internally generated revenue as predictors of sustainability of University education in Cross River State, Nigeria $(\mathrm{N}=186)$

\begin{tabular}{lccccr}
\hline Variables & SS & Df & MS & F-ratio & p-level \\
\hline Regression & 4426.676 & 7 & 632.382 & 33.070 & $.000^{\mathrm{b}}$ \\
Residual & 4551.162 & 179 & 19.123 & .702 & \\
Total & 8977.837 & 186 & & & p-level \\
\multicolumn{7}{c}{ Unstandardized Coefficients } & Standardized & T & & \\
Variables & \multicolumn{2}{c}{ Coefficients } & & & \\
\hline Constant) & $\mathrm{B}$ & Std. Error & Beta & & .000 \\
$\mathrm{X}_{1}$ School charges & 18.468 & 3.247 & -.100 & 5.688 & .000 \\
$\mathrm{X}_{2}$ Tuition fees & .871 & .158 & .332 & 5.525 & .734 \\
$\mathrm{X}_{3}$ Investment income & .057 & .168 & .024 & .341 & .000 \\
$\mathrm{X}_{4}$ Grants & .902 & .121 & .444 & 7.455 & .010 \\
$\mathrm{X}_{5}$ Gifts & -.293 & .113 & -.146 & -2.581 & .231 \\
$\mathrm{X}_{6}$ Consultancies & -.133 & .111 & -.066 & -1.202 & .002 \\
$\mathrm{X}_{7}$ Endowment & -.413 & .132 & -.238 & -3.124 & .005 \\
\hline
\end{tabular}

$* \mathrm{p}<0.05, \mathrm{R}=.702 ; \mathrm{R}^{2}=.493 ;$ Adj. $\mathrm{R}^{2}=.478$

The result showed that $\mathrm{R}=.702$. This implied that management of internally generated revenue variables are strong positive predictors of sustainability of University education. More so, the adj $\mathrm{R}^{2}$ showed a coefficient of .478 which implies that the variability significance of sustainability of University education can only be clearly explained by the selected sub-variables of management of internally generated revenue. However, a cursory look at the analysis of variance (ANOVA) result showed that although the percentage contribution was small, $(\mathrm{F}=33.070, \mathrm{p}<.05)$, and $\mathrm{p}(.000)$ is less than $\mathrm{p}(.05)$, it implied that the null hypothesis is rejected. Thus, there is a significant joint effect of management of internally generated revenue variables on the sustainability of University education. Nevertheless, looking at the relative effect of the variables, the result showed that management of internally generated revenue in investment income is the strongest predictor $(\beta=.444, p<.05)$ followed by school charges $(\beta=.332, p<.05)$, then, consultancies $(\beta=.-238, p<.05)$, endowment $(\beta=.184 \mathrm{p}<.05)$ and then grants $(\beta=-.146, \mathrm{p}<.05)$,

\section{DISCUSSION OF FINDINGS}

Management of internally generated revenue and the sustainability of University education. The result of data analysis on this hypothesis revealed that the management of internally generated revenue significantly influences the sustainability of University education. The implication of this finding is that, the higher the level of management of internally generated revenue, the higher University education sustainability could be ensured while the lower level of management of internally generated revenue, the lower the sustainability of University education in terms of quality teaching, learning facilities, school environment and the overall sustainability of University education.

The findings of this study is in line with the findings of Ofoegbu \& Alonge (2016) who found that there was a significant relationship between internally generated resources and the management and development of universities in Southern Nigeria. It also corroborates Afutu (2015) who found that most of the sources of Internally Generated Fund for the university can be sustainable by constant increase of enrolment and commercialization of departmental activities like printing/ publication section and clothing service department.

In the same vein, the finding is in consonant with Adesoji and Chike (2013) that there is a positive relationship between internally generated revenue and infrastructural development for educational sustainability. The study also revealed the various methods of generating internal revenue, which are the enforcement of tax personnel, contribution, and creating awareness to the public. The findings of the study however showed that revenue administration agencies need to be reviewed to generate more revenue in the country. Also, in line with Aja-Okorie (2017) that the University partnership programmes or collaboration with other institutions can improve the University internally generated revenue base and that adoption and efficient utilization of e-payment of school fees and online registrations can help to increase the Internal Generated Revenue of the University. The findings also agree with Wordu (2018) that the Federal and State institutions had disparity in the sources of 
internally generated revenue, and there is no doubt that the internally generated revenue initiative of tertiary educational institutions in the state is at its early stage of development.

It equally agrees with Akinsolu (2012) whose correlation matrix table showed that all variables of resource utilization had positive relationship with internal efficiency. This attested to the fact that resources are vital for educational system production function. It aslo agrees with Omodere, Ekwe \& Ihendinihu (2018) who found that TIGR, SIGR and LIGR have robust and significant positive impact ( $\mathrm{p}$-value $=0.000<0.05$ ) on RGDP, while FGIR also indicated positive and significant influence on RGDP. There was an existence of high correlation between the dependent and independent variables.

The brain behind this finding could be that management of internally generated revenue of the institutions of higher learning stems from the intangible resources that accrue from commercial ventures, research and consultancy services, manufacturing/fabrication of tools and other sources of internally generated revenue which support the University to achieve tangible/visible transformation in the quality of teaching, learning facilities and the infrastructural landscape of the institutions. These further translate to meaningful achievement of the tripodal roles of the university system namely teaching, research and community services.

\section{CONCLUSION}

The result shows that a large majority of university administrators are of the opinion that IGR reduces the problem of underfunding and over reliance on government for funds, the scarcity of which has remained a clog in the wheels of effective management of University education in Nigeria. It also shows that IGR if properly managed will ensure positive transformative changes with a propensity for more progress. Therefore based on the findings of this study, the researchers have logically concluded that commercial ventures were the major sources of IGR. Without fallacy, there is a significant influence of the management of IGR on the sustainability of University education in Cross River State of Nigeria.

\section{RECOMMENDATION}

Since IGR serves the interest of educational purposes it must be set up to actualize the ideals of University education. The following recommendations are therefore made:

(I) The funds which are generated internally by the university need to be managed judiciously to achieve sustainable development goals of the University.

(II) Implementing an automated revenue management system can be a crucial step for the University to improve fee collection and increase revenue for successful turnaround education solutions that put them on a course for success. This smart software enable administrators to streamline fee collection including creating fee structures based on various combinations and dependencies for every student, collecting payments, generating receipts, and tracking these records in real-time. Innovative fee software reduces staff workload and help educational institutions to operate at the highest level of efficiency for sustainability. The software is designed to enable institutional administrators to enjoy hassle-free fee collection and enable parents to pay fee online without the need of standing in long queues because it is:

1. Customizable and scalable cloud \& mobile based fee management system

2. Easy-to-use \& deploy

3. Auto-calculation of various fees

4. Highly secure with role-based permissions \& privileges to users

5. Track fee payments of your various accounts from anywhere, anytime

6. Stay up-to-date on fee collection for any period at your fingertips

7. Prevent fraud and maintain privacy \& secrecy

8. Customizable fee structure according to your needs

9. Automatic backup \& upgrades

10. Collect fees in multiple installments and increase revenue

\section{REFERENCES}

Adeniyi J. O. (2014). Entity, ownership, educational subsidies and funding of Nigerian tertiary institutions: Current research. Journal of Social Sciences, 4(1), 56-61.

Adesoji, C. \& Chike, O. (2013). Systems and strategies for funding Nigerian Universities. A paper presented at a lecture on innovative and administrative effectiveness of university administrators in Nigeria.

Afutu, C. O. (2015). Modes of funding Nigerian Universities and the implications on performance. A paper presented at the 2011 Barcelona European Academic Conference, Spain.

Aja-Okorie, M. N. (2013). Strategies for improving the internally generated revenue base of Enonyi State University, Abakaliki, Nigeria. Journal of Educational Studies and Practice, 11(3), 76-102.

Akinsolu, I. A. (2012). Resource factors as correlates of secondary school effectiveness in Ekiti State. Nigeria Journal of Counseling and Applied Psychology, 1(1), 109-115. 
Akpan, A. (2015). Education budget and its implications (Analysis). Vanguard Newspaper.

Bamino, O. I. (2017). Alternative modes of financing higher education in Nigeria and implications for university governance. In J. B. Babablola, \& B. O. Emunemu (Eds.), Issue in higher education, research evidence from Sub-Saharan Africa. Lagos, Bolabay Publications.

Edet A. O. \& Osika E.O. (2018) Exploring alternative strategies of financing public secondary schools for sustainable development in Cross River State, Nigeria. Journal of Education and Practice. 2(34), 87-104.

Gayford, O. (2018). Adequacy-inadequacy: Education funding in Nigeria. Universal Journal of Education and General Studies, 2(8), 239-254.

Higgs, M., \& Macmillan, S. (2016). Funding Strategies for Quality University Education in Nigeria: The Principle of Fiscal Justice. Journal of Studies in Education, 1(1), 11.

Mohammed, L., Ahmed, D., \& Salihu, I. (2015). New and alternative sources of students' support and funding. Retrieved on 6/9/2016 from http://www.ed.gov/oi

Ofoegbu, K. \& Alonge, L. (2016). Leadership for school restructuring. Educational Administration Quarterly, 30(4), 498-518.

Omodere, B., Ekwe, F., Ihendinihu, J. (2018). Vocational technical education, the state and citizenry in Nigeria. A paper presented to the school of vocational education, the Federal college of education (Technical), Akoka on Thursday 27 th January.

Otemewo, P. O. (2018). Repositioning Nigerian Universities for national sustainable development. A paper presented at the 10th Iju Quarterly Public Affairs Forum Series, Ondo State, Nigeria.

Percy-Smith, O. I. (2018). Alternative modes of financing higher education in Nigeria and implications for university governance. In J. B. Babablola, \& B. O. Emunemu (Eds.), Issue in higher education, research evidence from Sub-Saharan Africa. Lagos, Bolabay Publications.

Uchendu, C. C. \& Akuegwu, B. A. (2016). Educational management: an overview. In C. C. Uchendu \& B. A. Akuegwu (Eds). Educational Management: a guide for practitioners.

Uzoigwe, M. C. (2018). Management of support services and teachers' task performance in Ebonyi State public secondary schools, Nigeria. A published Master of Education Degree Thesis submitted to Graduate School, University of Calabar, Calabar, Nigeria.

Wordu, L. O. (2013). Financing higher education in Nigeria: The Role of Internally generated revenues and how University Management can maximize the sources. UNESCO. (2010). Education for all global monitoring report. UNESCO. 